\title{
The Men in the Life and Work of Olga Kirsch ${ }^{1}$
}

\author{
EGONNE ROTH
}

\author{
Bar-Ilan University \\ Department of English \\ Bldg 404, "Wolfson Building" \\ Bar-Ilan University \\ Ramat Gan 52900 \\ Israel \\ eeeroth@hotmail.com
}

\begin{abstract}
Olga Kirsch's life and work was dominated by three men: her father Schmuel M. Kirsch, her youth lover Ellis, and her husband Joseph Gillis. Their presence can be felt throughout her oeuvre, both in her published Afrikaans and in her unpublished English poetry culminating in a collection of seventy-seven poems written in the months that followed the death of her husband. Through these poems the reader is introduced to a passionate side of Kirsch's personality that was rarely seen by those who knew her in the normal course of her life. These three relationships resulted in some of Kirsch's most beautiful poetry, of which her "Vyf sonnette vir my vader" is probably the best known.
\end{abstract}

Keywords: Olga Kirsch; Afrikaans; Jewish poet; woman poet; gender studies; Afrikaans literature

Three men dominated the life of Olga Kirsch. They were three of the most important sources of inspiration for her poetry. In each collection she published in Afrikaans and in much of her unpublished work in English, the presence of at least one of these men can be detected: her father Sam Kirsch, the lover of her youth Ellis, and her husband Joseph Gillis. In this article I will introduce

\footnotetext{
${ }^{1}$ This article is based on my doctoral research into the life and work of Olga Kirsch, carried out under the supervision of Professor Jeffrey Perl. It is based on extensive interviews in South Africa, Israel, England, and the United States; material drawn from various archives in each of these countries; and unrestricted access to Kirsch-related documents in the possession of her family and friends. All this material will eventually be transferred to an archive in South Africa.
} 
these three men using published Afrikaans poems by Kirsch as well as hitherto unpublished English poems. Using both the poetry and new information gathered in the course of my research, I will show how each of these men had an impact on Kirsch's life and poetry. Many of her poems that deal with relationships are strongly autobiographical and proved to be a useful guide in researching her life. There are, of course, exceptions such as the Blokhuis [Blockhouse] poems in her second volume of poetry, Mure van die hart [Walls of the Heart / The Walled-in Heart], but these poems fall outside the scope of this article.

Kirsch's father, Samuel Meyer Kirsch, a Jew from the village of Plungè/ Płungiany in western Lithuania (Kirsch 1994: 13), was a forceful man with dark curly hair and bright blue eyes. He came to South Africa in 1910 carrying one small suitcase and a violin (Human 2009). Like many of his countrymen, he left Lithuania, then still part of the Russian Empire, because of the increased incidence of anti-Semitic pogroms and the financial hardship of life in Lithuania (Newman 2006). He was ambitious, energetic, and prepared to work hard. Within ten years of arriving in South Africa, he had established a trading business in the village of Koppies in the Orange Free State, and had begun to buy up farms in the area. He married the Jewish Eva Nathenson, thirteen years his junior (Kirsch 1982unpublished), whose father had also come from Plunge in Lithuania. Together Sam and Eva worked diligently to expand and consolidate their business. By the time of Sam's death in 1937 at the age of fifty, Eva inherited a business and properties that ensured she did not have to work outside the home again after her fortieth birthday. She would be able to move among the three continents on which her children eventually lived - South Africa, the United States, and Israel - without being a financial burden to any of them (Hirschman).

Sam and Eva raised five children in a home where industry, active participation in the Jewish community (Koppies had its own synagogue and Zionist organization), and education were the driving values. Though Sam often came home tired after a long day's work, he enjoyed making music with his wife. Olga's younger sister Janette recalls drifting off to sleep to the sound of her father playing the violin while her mother accompanied him on the piano and sang. The children were bright and talented, but it was only for his middle child Olga that Sam considered the local high school inadequate. Olga was sent to boarding school at Eunice Girls' High School in Bloemfontein, the regional capital, because Sam believed the level of education would be higher there. In addition, Olga wanted to study Latin, which was not offered at the Koppies high school (Hirschman). Olga was particularly close to her father, as illustrated clearly in a photograph taken of the family around the time of her older brother's bar mitzvah when Olga was nearly eleven years old. It is a traditional photograph, typical of the 
time, with Sam Kirsch dominating the composition and Janette, the youngest child, sitting on her mother's lap. Olga stands smiling beside her father, her left hand resting in a proprietary manner on his leg, while her brothers are on the far side of their mother away from their father. Becky stands between her parents, her right hand resting on her mother's chair back. This important relationship between father and daughter is the central theme of a group of Kirsch's poems titled "Vyf Sonnette vir my Vader" [Five Sonnets to my Father], published more than thirty years after her father's death.

Olga Kirsch's life was shaped in many ways by her father Sam. While he lived, he was an example to his children of the value of hard work; together with Eva, he instilled a love of music and learning, and taught them the importance of Zionism (Hirschman). But it was Sam's early death shortly after Olga's thirteenth birthday that, according to her school friend Arnold Shapiro (2009), triggered her writing of poetry. Janette remembers that her sister Olga was writing verses even before she went to Eunice and their father's death, but no evidence of this has been found. The first poems published by Olga Kirsch appeared in the Eunice High School Magazine: one Afrikaans poem in 1940 and, during her last year at school, in 1941, both an Afrikaans and an English poem. The 1941 Afrikaans poem was titled "Sononder" [Sunset]:

Eer dat ek my oë sluit,

In die slaap van ewigheid,

Wil ek 'n toneeltjie sien

Wat my vrede toe sal dien

Na die lange lewensstryd.

Sonlig wat virlaas nog gluur

Op die vensters en die muur.

Trane-oё, diep bewoë,

Wat kykies in die toekoms stuur.

Rietjies rits'lend langs die dam,

Vaak geblêr van ooi en lam,

Populiere fluister dromend

Van die nag wat, duister komend,

Skaduwees van purpur verf,

'Wyl die daglig stadig sterf.

\author{
Before I close my eyes, \\ In the sleep of eternity, \\ I want to see a scene \\ That will give me peace \\ After the long struggle of life. \\ The sunlight still reflects one last time \\ on the windows and the wall. \\ Tear-filled eyes, deeply moved, \\ Try to glimpse the future. \\ Reeds murmuring along the dam, \\ Tired bleating of ewe and lamb, \\ Poplars whispering dreamily \\ Of the night, that with growing darkness \\ Paints shadows of purple \\ As slowly the daylight dies.
}

[translation by Egonne Roth ${ }^{2}$ ]

\footnotetext{
${ }^{2}$ Unless otherwise noted, all the translations in this article were done by the author. They are faithful to the original and enrich our understanding of the poet as a person, at times providing biographical information. Their purpose here, therefore, is functional rather than literary.
} 
While the poet may still be young and inexperienced - Olga was just seventeen when she wrote this poem - she confronts the reality of death. Going to sleep each night is like a little death, losing consciousness without the absolute surety of waking up. This fear of death may not be common among children, but seems to relate directly to her father's unexpected death a few years earlier. Sleep as death is a metaphor found repeatedly in Western literature. Shakespeare, for example, uses it in Hamlet: "To die, to sleep [...] that sleep of death." Olga would have studied more than one Shakespeare play by her final school year. ${ }^{3}$

The end of the day (line 1) is often an image used to refer to the end of life because of this association, old-age homes were frequently called "Awendrus" [evening rest]. The melancholy evoked by the "skemeraand" [dusk], which Eugène Marais has called "Hesperian depression" or "evening melancholy" (1984: 1162), continues in much of Kirsch's poetry throughout her life, even when not directly related to dusk. It is especially present in Afskeide and her English poems following the death of her husband when she experiences herself in the twilight of her life. The references in this poem to the reeds near the dam, the tired bleating of ewe and lamb, and the poplars set this poem in a rural area such as the Koppies district. The influence of the poem "Eensaamheid" by Jan F.E. Celliers (1934), who died the year before Kirsch's poem was published, is evident: her use of diminutives such as "toneeltjie," "kykies," and "rietjies" probably derives from Celliers's repeated use of "vuurtjie" as well as "stemmetjie" and "deuntjie." In both poems the general feeling of melancholy and loneliness is evoked by her (and his) use of the veld, the bleating of the animals, and the deepening dusk. In later poems addressed to her father, she also describes his life as a "lifelong struggle." The speaker is therefore probably meant to be her father: Sam died unexpectedly in 1937 (Death Certificate 1937). Through this poem and later poems written as an adult, Kirsch was able to explore how she (and her siblings) experienced their father's death: sadness that his whole life had been a struggle for survival and efforts to provide financial security for his family, but that he had had little time to enjoy the fruit of his labours. We will see later that the regret of not having known him better as a child and the sense of loss that could not be redressed become dominant themes in Kirsch's poetry about her father. But as she was growing up and forging her own path, her father became the measure by which the men with whom Kirsch became involved would be judged. In

\footnotetext{
${ }^{3}$ It has been impossible so far to locate the prescribed books, plays, and poems that Olga Kirsch would have studied in school. Neither the Free State Department of Education nor the archives were able to respond to my queries successfully. However, it can be safely assumed that some works by Shakespeare were prescribed during Kirsch's school years as this was common practice in South Africa. An internet search shows that world-wide the most common plays to be studied at schools are Romeo and Juliet, Macbeth, Hamlet, Julius Ceasar, A Midsummer's Night's Dream and Othello.
} 
these early years, Kirschwas not ready to explore the issues surrounding her relationship with her father and - not long after writing the poem above - a young man entered her life who led her writing in a new direction.

At the end of Kirsch's final school year, the family moved to Johannesburg where she enrolled at the University of the Witwatersrand for a B.A. degree, majoring in Afrikaans and History (Wits Archive). It was during 1942, her first year at university, that she met and fell in love with Ellis, a Jewish engineering student who, like her, had grown up in an English speaking home (Yudeiken $S$. 2009) and who would inspire much of her poetry over the coming years, even after their love affair ended. Not only did he become her boyfriend, but the two families became well acquainted through their relationship. Kirsch describes the relationship in her first collection of poems published in Afrikaans in August 1944, titled Die soeklig [The Searchlight]:

Al die onversadigde verlange,

Al die verwagtinge, die vae drange

Van ons jong liefde, ken ek in die skemeraand, wanneer die miste langs die hellings swel en val, stilswyend die bleek, vaal sterre uit hul voue skud, en wegwyk weer na verre.

Dan voel ek weer my siel verruim en vul met daardie skoonheid wat ons liefde is soos eens, toe ons tesame was, omhul deur awendmiste wat in wispe krul, toe ons vervul was van 'n stil genot wat mens so menslik maak, so na aan god. (Kirsch 1944: 16)
All the unfulfilled longings,
all the expectations, the vague cravings
of young love, I know in the evening dusk
when the mists along the slopes swell
and fall, silently the pale, dull stars
shaken from their folds, and move afar.
Then I feel my soul expand and fill
with the beauty that is our love
as once, when we were together, wrapped
by evening mists that entwined us in wisps,
when we were filled with a quiet joy
that makes us so human, so close to god.

In this poem the poet demonstrates her ability to create mood by using elements from nature. She wraps the memory of being with her lover in images such as "skemeraand" [dusk], "miste" [mist] and "bleek, vaal sterre" [pale, dull stars], which suggest a lack of light and diminished visibility so that they may be hidden. The speaker feels her "soul expand with the beauty that is our love," until she feels both human and close to god (Kirsch does not capitalise God as is traditionally done). A similar atmosphere is found in the poem, "Illusie" [Illusion], also in this collection: 
Soms as ek in die silwer skemering stap met oë half-toe, want die ligte reën prikkel my wange, dans en trippeltrap verby my lippe en om my oë heen, dan sak die stilte in 'n klammevlaag oor alles, donkergroen en silwergrys die denne, en ek slaan my jas se kraag hoër om my nek.Daar is iets wat eis dat ek met eens met ligter tred moet gaan, met tintelende ekstase in my bloed. Dalk aan die einde van die lange laan gaan ek jou, liefste, ylings tegemoet. (Kirsch 1944: 34 )

\author{
Sometimes when I stroll in the silver dusk \\ with eyes half-closed, little drops of rain \\ tickle my cheeks, dance and pitter-patter \\ past my lips and around my eyes, \\ the silence descends on everything \\ in a damp gust, dark green and silver-grey \\ the firs, and I turn my coat's collar \\ higher around my throat. Suddenly, something \\ urges me to go with a lighter tread, \\ with tingling ecstacy in my blood. \\ Maybe at the end of the long lane \\ I'm coming hurriedly, my love, to meet you?
}

[translation by W.F.T. Minnaar]

Again the poet uses the image of dusk and now light rain, instead of mist, that blurs her sight, but the words "sometimes," "something," and especially "maybe" in the penultimate line strengthen the feeling of longing for her lover. The action of drawing the collar of her coat closer around her neck imparts a feeling of warmth and evokes the tingling expectation that she may see him after all. Yet she may not. This poem was written at a time when many young South African men, including those from the Jewish community, volunteered for the armed forces and went north to fight the Axis powers (Yudeiken I. 2009). Kirsch's boyfriend also enlisted (Yudeiken S. 2009) and so he is the young soldier who goes to war in this collection. It is uncertain when this poem was written in relation to Ellis's departure for the front. However, her response when he actually leaves is described in the opening quatrain of a sonnet, also in Die soeklig:

Iets het gesterf in my met jou vertrek; Something diedinmewithyourdeparture;

iets wat ekstaties was, en bly spontaan, something ecstatic and joyfully spontaneous,

onverantwoordelik soos'n lentewaan, irresponsible asaspringillusion,

het drup-drup uit my wese weggelek. leaked from my being - drop by drop.

(Kirsch 1944: 30 )

There can be no doubt that the uncertainty reflected in some of the love poems to Ellis stemmed from her fear that he might die on the front, as she expresses in "Ontwaking" [Awakening]: "Ennaak en vreesbevange staan ek voor verganklikheid" [Naked and terrified I stand before transience]. By the time he left in the autumn of 1943 , reports of casualties were already part of the regular news. Yet more than one poem carry indications that the speaker doubts the love they share. She writes: 
Is dit'n droom, verwronge, vreesvervul, of is dit werklikheid - dalk die besef dat liefde ook mag wankel en vergaan (Kirsch 1944: 8)
Is this a dream, distorted, filled with fear, or is it reality - perhaps the understanding that also love might falter and perish -

Here it is clear that the poet is unsure that their love can last, maybe because she is unsure of herself and needs reaffirmation. At other times she is strong and certain of their love, certainly of her love for him as she describes her feelings in the last line of the first poem in the collection: "my liefde, diep en innig, sterk en stil" [my love, deep and intimate, strong and still] (Kirsch 1944: 5). If she was this sure of her love for him, is it possible that she doubted his love for her? Kirsch, though from an English-speaking home, addresses her English-speaking boyfriend in Afrikaans. Her choice of Afrikaans as the language of her poetry has been explained by her daughter, Ada Zohar, with the words "Afrikaans was the language of my mother's soul" (Zohar). It was the language of her childhood in Koppies and of the first seven years of her education, but Ellis shared neither of these experiences.

Ellis was not the man for whom the elegies in her second collection, Mure van die hart, published in 1948, were written. The poet does not reveal to whom these elegies in the first or second collection are dedicated. He had returned from Italy early in 1945, discharged due to a hernia he developed from loading and unloading the supply trucks he was driving (Yudeiken S. 2009). The relationship between the young couple had not resumed and grown in the way Kirsch had hoped, but dissipated until Ellis left again on a different kind of adventure in 1946. In this collection, Kirsch describes the morning he left for the second time:

Jy is reeds buite roepstem of bereik, Want vroeg vanoggend het hy steil geklim, Gesirkel en gedring verby die kim

- die vliegtuig wat jou wegvoer - hy wyk

Uur vir uur verder oor die vasteland

En oseaan. En tog het dit bestaan,

Die afstand tussen ons, lank voor jou gaan.

(Kirsch 1948: 29)

\author{
You are already beyond call, out of reach, \\ because early this morning it climbed steeply, \\ circled and driven beyond the horizon \\ - the aircraft that carried you away - and moved \\ hour after hour further across the continent \\ and ocean. And yet it existed, \\ this distance between us, long before you left.
}

Twice he left both her and his studies - the first time to go to war and the second, to pilot the plane of a man who wanted to escape the law and reach England (Yudeiken S. 2009). Neither the relationship with Kirsch nor his studies could compete with this offer for adventure. This is why she writes in the last line 
above that the distance between them had existed even before the plane carried him out of sight. As a result, she cautions her heart in the final line: "hart, nou moet jy ophou hoop" [heart, now you must stop hoping] (Kirsch 1948: 29).

Yet she found it difficult to obey her own warnings and those of others. Her family had not been supportive of the relationship even though Ellis's mother and Olga's mother Eva became close friends, and they played bridge together until months before Eva died. While Ellis may have been well-built and handsome like Olga's father, he was in no way the man Sam had been. Though adventurous, Ellis lacked Sam's sense of purpose in life. As a young man, he did not have Sam's vision or aspirations. He was not interested in having a family for whom he would have to take responsibility. In fact, it became clear that Ellis had not been faithful to Olga during the war in Europe, and this was unacceptable to Olga, as well as to Eva and Henry, Olga's older brother, who was protective of his pretty, younger sister. Years later, in the only English poem written about Ellis, Olga recalls:

1943

When the boy who would not marry me

went off to war

alien in khaki and beret,

in terror of death and maiming,

hankering for the new,

he gave me a picture of himself

a likeness, but poor:

eyes nose mouth curls were there

spirit was gone -

the photographer delayed the flash

too long.

I could not bring those eyes to life

no matter how I gripped the frame and gazed -

the paper face had driven out the flesh.

I listened for the voice that used to twang

strings in the hollow of my belly -

nothing came.

And yet that pallid absence stood two years

between me and the flesh-and-blood boys.

(Kirsch - unpublished, undated)

The title of the poem informs the reader when Ellis left for the war. In the first line she refers to her lover as having been like a boy, not a man ready to take on 
responsibility. In line 3 she describes him as alien in his army uniform. Was this merely because he looked so different or was it because she sensed already at his first departure that their love for each other differed in its seriousness? The last line suggests the sense of loss the poet felt for the time she had wasted waiting for him. Yet the poem also clearly shows that, even as a much older woman living in Israel and happily married, the poet can still clearly recall her love for this young man and the impact of his unwillingness to commit to her.

The final break with Ellis may have been a contributing factor to Kirsch's decision to leave South Africa for Israel shortly after publication of her second volume of poetry. There were, of course, additional factors: her troubled relationship with her domineering mother ${ }^{4}$ and her strong Zionist beliefs fostered in a home where her father had been vice-chairman of the local Zionist Society in Koppies (Diaspora Museum). Throughout the second section of Mure van die hart (1948), the poet expresses her earnest desire for her people to be restored to their homeland. Thus, it would be expected that when the dream was miraculously fulfilled in May 1948, Kirsch would join those who went to rebuild it. She arrived in Israel in November 1948 (Telfed ${ }^{5}$ ) and immediately set about looking for work there. One interview was with Dr. Joseph Gillis, a mathematician at the Weizmann Institute in Rehovot, who needed a secretary (Zohar). Gillis was a Cambridge graduate who had worked at Bletchley Park on breaking the Enigma code (Bletchley Park Archive) and had been personally invited by Dr. Chaim Weizmann to join his team of researchers at the Weizmann Institute in Rehovot (Gillis, J. - recorded interview). Instead of a job offer, Joe, as he was known, made Kirsch a marriage proposal. He had fallen in love with the pretty immigrant from South Africa with her dark curly hair and hazel-green eyes and would never fall out of love with her (Zohar). Kirsch did not accept his proposal immediately, but decided to travel to a kibbutz near the northern border, Ma'ayan Baruch, to assess the offer. Life on the kibbutz was very different from anything Kirsch had known and it took her three months to decide to accept Joe's offer. Her mother joined her in Tel Aviv to help make the wedding arrangements. Olga Kirsch and Joe Gillis were married in a small hall in Tel Aviv on 3 July 1949 (Marriage Certificate). Kirsch was not in love with Gillis as she had been with Ellis, but she probably understood that she could grow to love him and she did. He was everything Ellis had not been and the similarities between Joe and Sam, her father, were

\footnotetext{
${ }^{4}$ In her 1982 collection Afskeide, Kirsch repeatedly refers to the problems they experienced and reflects on how she found new compassion and understanding for her mother - this subject deserves a more comprehensive discussion than possible in this article.

${ }^{5}$ Telfed, the South African Zionist Federation, opened its offices in Israel in 1948 to give support to the South Africans who went to fight in the Israeli War of Independence. Subsequently, they specialized in facilitating the integration of immigrants from Southern Africa to Israel.
} 
remarkable: Both were ambitious, focused, with a clear sense of direction in their lives; and both Sam and Joe were committed Zionists. Furthermore, Sam had been thirteen years older than Eva, as Joe was thirteen years older than Olga. Gillis offered many of the things that were important to her and living on the grounds of the Weizmann Institute would be more in keeping with the values that Sam and Eva had instilled in their children. Together, Gillis and Kirsch would build a relationship and a home that was an inspiration to their two daughters and to many of the people who visited them (Yoffe, B).

More than two decades after leaving South Africa, Kirsch began to publish in Afrikaans again, and among her first poems to appear were the "Vyf Sonnette vir my Vader" (1971). While deeply involved in her life as wife and mother, Kirsch was not ready to write about her husband yet - not until she found closure with regard to her father's death could she fully address her love relationship with Gillis. Each of the five sonnets deals with a different aspect of her relationship with her father Sam. All five sonnets are addressed to him, and the reader cannot help but feel like an eavesdropper on a very personal conversation between father and daughter. In Sonnet I, she tells him how much she had wanted to belong to the small community in which she grew up and how she resented the fact that his speech identified him, and her by extension, as foreign. The sense of being an outsider remained with Kirsch and presents itself throughout her oeuvre. ${ }^{6}$ Language would also remain a central issue for Kirsch, expressed throughout her work. English had been the language in Kirsch's childhood home as it was Eva's mother tongue, while Sam came from a Yiddish-speaking home. The children never learnt Yiddish except for the common expressions and idioms which form part of most Jewish homes (Hirschman). In South Africa, Sam had to acquire a working knowledge of both English and Afrikaans. That Kirsch chose to write to her father in Afrikaans should be understood in light of the fact that Koppies remained the place of childhood memories in which Sam was the dominant presence, and Koppies meant Afrikaans for Kirsch. Because Sam worked such long hours to create a stable base for his family, he was hardly ever available to his children. As a result, the first sonnet ends with "het ek jou skaars geken" [I hardly knew you]. Sonnet II continues this theme, opening with, "'n Duisend duisend vrae sou ek jou stel / as ons nou langs mekaar kon sit" [A thousand thousand questions I would put to you / if we could now sit side by side] and

\footnotetext{
${ }^{6}$ Prof Andries Wessels explores this aspect of Kirsch's work (2009), and there is thus no need to linger on it here. Wessels shows that Kirsch holds a position of liminality in Afrikaans poetry: Though recognized as an important, even beloved poet within the tradition, Kirsch is at the same time identified as an outsider in terms of culture and religion (which are central to her work), outside the Calvinist Christian tradition closely associated with mainstream Afrikaans culture - a culture which has, of course, been marked by racial exclusiveness.
} 
closes with "En nogmaals hoe en wat en waar en wie?" [And once again how and what and where and who?] (Kirsch 1971) In this sonnet the reader once more senses the deep sorrow of the speaker at not knowing her father better. There are so many questions that need to be asked and answered, but he is dead and they can never have the conversations for which she longs. Sonnet III begins similarly in that the poet acknowledges that much of what she knows about her father is based on guesswork:

\begin{abstract}
Al my gegewens grens aan die miskien: Uit 'n portret (geneem daar anderkant?) deftig, met hoed en kierie in die hand staar jy, 'n jonkman van dalk sewentien wat straks vertrek uit sy geboorteland. Besliste mond en kin, opreg, kordaat in jou verloor die tsar 'n knap soldaat, wen Afrika 'n brawe immigrant.
\end{abstract}

O Vreemde weë, vreemde stede en sterre. Al was 'n skaar van mense vir jou goed, al was hul mense van jou bloed kon jy jou soms siek hunker na die verre waarheen geen terugkeer was.

Hoe weet ek dit?

Het ek nie daardie swerftog voortgesit? (Kirsch 1971)
All my premises border on the perhaps:

From a portrait (taken there on the other side?)

elegant, with hat and cane in hand you stare, a bachelor of maybe seventeen perhaps departing from the land of his birth. Resolute mouth and chin, straightforward, strong in you the tsar loses an able soldier,

Africa wins an upright immigrant.

O Strange roads, strange cities and stars.

Even though a host of people were good to you, even though they were people of your own blood did you sometimes, sick with longing, yearn for those faraway places to which there was no return.

How do I know that?

Have I not embarked upon my own odyssey?

$$
\text { [translation by C. Lasker] }
$$

In this Italian sonnet, comprising two stanzas, an octave and a sestet, the speaker speculates about her father's experiences as an immigrant. In the first stanza, she tries to recapture from the only photograph she has of him as a teenager what he must have been like at the time of his immigration. This photo still exists, and the young man does look as though he is in his middle to late teens - "maybe seventeen." However, as it is now known that Sam immigrated in 1910 (Hirschman) when he was already twenty-three, it appears that at the time of writing the poems, Kirsch was not aware of these facts. Her sense of not having known her father is clear in this first stanza given words such as "grens aan die miskien" [border on the perhaps] in line 1, "dalk" [perhaps] in line 4 and "straks" [perhaps] in line 5. The words "miskien" and "straks" have both been translated by the word "perhaps." The use of different words in the Afrikaans 
may be seen as stylistic variations but could also be interpreted as the poet showing her struggle to express her feelings regarding her lack of information about her father. Also in the opening line "grens aan die miskien" [border on the perhaps], she is saying that her information may not even be correct - it only borders on it, one step removed from "really" knowing to "perhaps" knowing. This elaboration of the concept of not knowing challenges the reader to consider "What do I really know about my father, my parents?" The personal thus becomes the universal. Adding to the poignancy of the sonnet is the speaker's obvious pride in her father - the tsar's loss was Africa's gain.

There is one aspect in which she feels she does understand him, namely that of being an immigrant. She writes about this in the second stanza, which reflects her own experience in immigrating to Israel, but even more convincingly, her imagined version of Sam's arrival in South Africa. Life in the newly established state of Israel was as strange to Olga as South Africa must have been for Sam. She echoes the Biblical concept - she and Sam were both strangers in a strange land. Not only were human artifacts like roads and cities strange, but also the stars of heaven. Nothing was wholly familiar - not even looking up at the night sky could bring them comfort because each had moved to a different hemisphere. She confidently asserts that she shares with Sam his realization that there could be no return to the land of one's birth - the political situation back there made this impossible for both. In Sonnet IV, the poet continues her description of her father's appearance, emphasizing that he was a source of stability and strength for her: "Vir my was jy die bron van alle krag" [For me you were the source of all strength]. She goes on to contrast his outward physical strength with an underlying vulnerability:

Een somerdag aan tafel skuif die mou hoog oor jou sonbruin vel en ek aanskou jou ronde boarm, bleek en bloot en sag en ek begryp hoe listig is die dood en trane het gemengel met my brood. (Kirsch 1971)
One summer day at the table your sleeve slipped up over your suntanned skin and I beheld your round upper arm, pallid and bare and soft and I understood how cunning is death and tears mingled with my bread.

The adult speaker remembers herself as a child becoming aware of her father's vulnerability as she sees the untanned part of his arm and is suddenly overwhelmed by the fear of losing him through death. The poet lost her father just after her thirteenth birthday, and here she seems to imply that even as a young girl she had realized that her father could die. More 
likely, however, Kirsch is portraying her own feelings of vulnerability after his early death. Having returned to her child-self in Sonnet IV, she recalls in Sonnet $\mathrm{V}$ a beloved memory of going with him to synagogue. The tone of the writing indicates that this was a privilege not to be taken for granted. In Orthodox synagogues such as the one in Koppies, men and women sat separately: men sat downstairs and actively participated in the service, while women sat behind a screen or in a gallery looking down. The closer girls came to their twelfth birthday, the less likely they were to sit with their fathers during the prayer service. After the age of twelve, they were not allowed to sit with the men but had to be in the gallery with the women. Similarly, boys older than thirteen could no longer accompany their mothers, but had to participate with the men. So it is not simply the act of going to synagogue that is important to the speaker, but the fact that she was privileged to sit with her father among the men and that when they rose for the prayers, he put his arm around her in a public display of affection. For the little girl this must have been a moment of pride and joy that remained vivid for the adult Olga. These sonnets first appeared in the December 1971 issue of Buurman and the following year were included in Negentien gedigte [Nineteen Poems]. After this collection, Kirsch would return to writing to her father only once more. This came in the collection Afskeide [Farewells] published in 1982 after her mother's death, when she dedicated the entire volume of poems to writing about her parents, including only two short poems at the end to her husband Joe. This is the only time both Sam and Joe are addressed in the same collection.

In 1975, twenty-seven years after leaving South Africa, Kirsch felt emotionally ready to return to the land of her birth and visit the village of her childhood memories. She told her daughter, Michal Lyons, that she had regularly dreamt of the South African landscape (Lyons). It was as if this visit closed the circle of her childhood and youth; when, eight months after returning from South Africa, she published her next volume of Afrikaans poetry, Geil gebied [Lush Land] in 1976, it included a selection of poems about her husband. She could now turn her attention to the man who had become her lover, friend, and companion: "Jy's minnaar, vriend, metgesel" (Kirsch 1976: 30). One of her most beautiful sonnets appears in this collection: Titled simply, "Huwelik" [Marriage], it describes the evolution of their marriage over the previous thirty-four years:

'n Jaar of wat van angs en fel verrassing, van leer en afleer, lugtige geluk, dan is daar kinders.Die pynlike aanpassing wat diens en arbeid verg, die onderdruk van self, lang dae en nagte sonder rus
A year or so of anxiety and intense surprise, of learning and unlearning, airy happiness, then there are children. The painful adjustment to service and labour, the suppression of self, long days and nights without rest 
maak dat hul al hoe meer mekaar beskou as ouers, bondgenote in kommernis en vreugde, maar bysaaklik man en vrou.

Skielik is dit ' $\mathrm{n}$ afgemaakte taak.

In leë kamers sien hul mekaar weer raak vergete rykdom.Albei het diep gely, veel prysgegee en baie bygekry.

In die stil huis ontdek hul weer mekaar soos, in 'n veraf tuin, die eerste paar.

(Kirsch 1976: 26) so that they increasingly regard each other as parents, companions in worry and joy, incidentally husband and wife.

Suddenly it is a completed task. In empty rooms they again notice each other forgotten wealth. Both have suffered deeply, sacrificed much and gained greatly.

In the quiet house they rediscover each other as - in a distant garden - the first pair.

In this Shakespearian sonnet, which follows the traditional rhyme scheme in the first two quatrains, Kirsch describes the three phases of marriage. There is the first period where "airy happiness" is offset by the problems of adjustment and the uncertainty of early marriage. This would have been especially true for Kirsch, who had not known her new husband for long. The second phase is that of having children with all the implications this entails, and when the children have grown up, the times comes that they are alone in their home again as a couple, but now with greater appreciation for each other. The assonance in the final couplet (line 13 ends "weer mekaar" and line 14 ends "eerste paar") strengthens the reader's awareness of the parallel drawn between the couple rediscovering each other and the Biblical story of Adam and Eve in the Garden of Eden. This association suggests the freshness and innocent joy they found in each other. In an unpublished interview, Kirsch's younger daughter Ada said that during her last years at home in the late sixties, after her sister Michal had been inducted into the army, she had seen her mother fall in love with her father. Once their daughters were married and busy building their own families and careers, Kirsch and Gillis found new passion in their marriage. "They were like a young, in-love couple," Zohar said. That new love is reflected in her poetry for the first time in this collection.

Jy keer op jou regtersy

as jy inslaap en word vir my

'n langsaam-kartelende kus

en ek die see wat wieg en rus

teenaan en kantelend van hom skei

in slaap se donkere laaggety.

(Kirsch 1976: 28)
You turn onto your right side

as you fall asleep and become for me

the leisurely-wavy shore

and I the sea that rocks and rests

against you and tumbling is divided from you

in sleep's dark low tide. 
Minnaar points out in his discussion of this poem that, as in other poems by Kirsch, the sea / water can be seen as symbolic of the female or mother, but it can also refer to the sexual (Minnaar 2012: 121). Given the sense of motion created by the verbs and adjectives in their meanings as well as their sounds, there is clearly a sexual reference here - the intimacy after love making. These expressions of loving intimacy also appear in several unpublished English poems written after the death of Gillis. I quote the opening lines of one such poem: "The fertile crescent / where bodies meet and merge, / embarked in each other, discover / the other and self." Again the verbs in both their sound and meaning suggest sexual intimacy.

As a result of this intimacy and the pleasure they found in each other's company, Kirsch accompanied Gillis on his travels whenever possible. They also shared many interests. The intense nature of their life together is described in another English poem written after the death of Gillis:

Today my mind flashes vignettes of you

on our holiday.

We lived together so long

that we thought the same thoughts

in the same pictures and words.

You cannot be utterly gone.

Somewhere today

you too are remembering Spain.

(Kirsch - unpublished)

As Kirsch recalls the last holiday she and Gillis shared, she is aware that only with him could the true nature of the memories that photographs evoked be shared. Hence, if her memories are so clear, it is unthinkable that he is no longer there to share them. In 1978 Kirsch had published an Afrikaans poem in which she told Gillis that they would always be separated by the difference of the languages in which they worked: he the language of mathematics, she the words and sentences of poetry (Kirsch 1978: 14). However, more than two decades later, by the time Gillis died, this had changed. They had begun to think in the same images and words. In her elegiac poems to Gillis written after his death, she does not revert to the earl forms poetry such as the sonnet she had used earlier. Rather, she often uses a slow rhythm to indicate the drag of time that his absence had brought into her life. Ordinary activities no longer bring pleasure as before, because Joe is not there to share them. 
That's twice I've cleaned the house

without you dusting or hoovering or both:

Once when I thought you were coming home

and now that I know you are not.

I've even done the chore I hate most -

washing the floors.

"That looks bright," you say.

"Can you really tell the difference?"

"Of course, it's clean."

(Kirsch - unpublished)

This poem opens a window into the everyday life the poet shared with her husband and we learn that he regularly helped her with simple household chores such as dusting and hoovering. Having to do these chores alone underlined her loss. The only way Kirsch could continue her life was to imagine the conversation between her and Gillis that might have accompanied an activity. The use of direct speech brings a sense of immediacy to this poem. Lines 3 and 4 indicate that she had not expected him to die in the hospital - it had happened without warning. In fact the morning Gillis was due to be released from the hospital after he recovered from a heart attack, he suffered a second attack and was dead before Kirsch could reach him. By sharing the intimate details of her sorrow, she draws the reader into the poem and her life.

This sharing of intimate information in her late poetry raises certain questions to which the answers are not as obvious as they may first appear. Kirsch wrote 77 poems to Gillis after his death in November 1993 - all in English. Yet she apparently wrote relatively few poems to him in English before he died and those earlier poems do not express the passion and intimacy between them as do the poems written after his death. In 1976 when the first poems to Gillis appeared in Geil gebied, Kirsch had already expressed doubts about her ability to continue writing in Afrikaans. Yet in each of her last three published collections, she chose to address her beloved husband in a language he did not understand. Gillis had shown no interest in learning Afrikaans. In fact, he had also shown no curiosity about her childhood in South Africa, which was one aspect of their marriage that she found hurtful. This was confirmed by her daughter in an unpublished interview (Zohar). In one of the few English poems written to Gillis during his lifetime, Kirsch directly addresses the issue: "Why can I tell you who recall so much / nothing about the time when I grew up?" And then she shares something of that "lonely childhood on the vast high plateau / where nothing stirred but the grass." His response or explanation has not been recorded. The question, then, is why did she continue to write to him in Afrikaans? The answer is possibly more 
complex than simply her love of Afrikaans. Kirsch was known as an extremely private person who did not easily share her feelings with those around her: Is it conceivable that she chose to express these intimate feelings and the pleasure of their sexual life together in a language that those whom she met daily could not understand, while those who could understand were far away and not part of her everyday life?

It would appear from comments Kirsch made during interviews that she only really started writing again in English ${ }^{7}$ after the publication of her last Afrikaans collection, Ruie tuin [Fertile Garden] in 1983. The transition must have been fairly quick, however, for an unpublished collection of fifty English poems exists that was written in response to her younger daughter's unexpected divorce in late 1984. These poems were neatly clipped together and numbered as though ready to be submitted for publication. In 1990, Kirsch self-published a collection of English poems titled Sitrya, written after the death of her oldest granddaughter in 1987. Except for a few individual poems published in $A R C$, the Israeli poetry journal, no other poems from her large English oeuvre were ever published. It seems likely that the aforementioned poem to Gillis could also have been written during these years. The tone is certainly different then in the poetry written after his death. Apart from these three "collections," there are numerous other undated English poems about various subjects, most relating in some way to familial issues and old age. Not one of the eight Hebrew poems that have been found addresses Gillis. No unpublished Afrikaans poems have been found.

Her father, her lover, and her husband were the three men who most informed her work. However, other men were addressed in her poetry, and there are numerous elegies to those who died in the war and afterwards. Except for a poem published in WU's VIEWS entitled "Resurrexit" that is dedicated to Alex Medalie and a poem in Negentien gedigte entitled "Sy naam was Sasha" [His name was Sasha], none of these men are identified. It is therefore possible that the poems were written in response to stories and news reports that Kirsch had heard. Who Sasha was is unknown. Sasha is sometimes the Russian version of Alex - many Russian Israelis are called Sasha by their families and Alex by others. However, given the content of "Sy naam was Sasha," it could not refer to Medalie. Kirsch's connection to Alex Medalie is also not clear other than that he was a classmate of her future brother-in-law at the University of the Witwatersrand in the early

\footnotetext{
${ }^{7}$ Little mention has been made in South Africa, other than by Daniel Hugo, of poems published by Kirsch in April 1966 under the title "Poems of Independence" in the Zionist Labour Journal, Jewish Frontiers. These poems constitute about a third of a manuscript titled Nevertheless that was found in 2010 among Kirsch's papers. This is a substantial text that deserves to become part of Kirsch's recognised oeuvrelike the other English manuscripts discussed in this article that have come to light in recent years.
} 
1940s. However, her father, lover, and husband are clearly identified when addressed in her poems. In only one poem, "Die Gestorwene" [The Deceased] (Kirsch 1944: 23) is there some doubt if the addressee is her father. Die soeklig, her first collection of poems, is the only Afrikaans collection bearing a dedication, "To E." Kirsch had wanted to dedicate it to Ellis but her mother vehemently opposed this idea and so mother and daughter reached a compromise: "To E" as it could refer both to Ellis and to Eva (Hirschman). For those who knew Ellis, the dedication was obvious. Also the contents indicated that it was addressed to a man with whom she was in love. She opens the last poem of the collection with the words "Hoe sal ek jou bedank vir al wat jy / aan my geskenk het met jou liefdeswoord" [How can I thank you for all that you / have given me with your love word]. These are not the words of a daughter addressing her mother, especially given that their relationship was often fraught with tension, as we learn from poems written to her mother in Afskeide. The final five lines of this poem confirm that her thanks are addressed to her lover:

Hoe salek jou my dankbaarheid betuig?

Weet jy, die wonder van jou liefde het

'n ryper wysheid in my siel gesmee;

ek ken nie meer my kragte nie, ek juig

net: Liefste, ek het soveel om te gee!

(Kirsch 1944: 36)

\author{
How will I show you my gratitude? \\ You know, the miracle of your love \\ forged a riper wisdom in my soul; \\ I no longer know my strength, yet I \\ rejoice: Beloved, I have so much to give!
}

The intimacy, longing, and at times uncertainty about herself is present in many of the poems to all three men. While Kirsch presented a cool, controlled exterior to the world outside, she was deeply committed to, and dependent on, the men she loved and this permeates her poems to them. At Olga Kirsch's funeral, her older sister told Chaim Beneven-Botha how only that morning she had reread some of Kirsch's poetry and realized, "I did not know my sister!"(Beneven-Botha 1998). Many would make a similar acknowledgement in the following years about their relationship with Kirsch. Yet through her poetry we discover not only her insecurities and questions, but more importantly the passion of her love - first for Ellis and even more so in later years for Joe. Kirsch described Gillis as her mentor, lover, and friend; her life was completely entwined in his so that his death left her struggling to find a reason to continue living. She wrote to him:

You would ask

before setting off for work

"What do you plan to do today?"

The question irritated me - 
I'd think, not say

"I can occupy myself."

But you were right, as usual.

Everything I did

had roots in you

and withers in this thin soil.

Services of love and custom

wove our pattern.

The warp's torn -

no weave with a single strand.

What shall I do with the days weeks months years

of the long life

friends wish me

(Kirsch - unpublished)

In this poem to Gillis, Kirsch returns to nature to illustrate how essential to her life he had been: He was the soil in which she grew and flourished. Her older daughter said, "My mother died of a broken heart," even though the medical diagnosis was death due to a brain melanoma. It is clear in this poem that without Joe, the silence became too heavy to bear. Nothing could compensate for his death - this is emphasized by the repeated use of words such as "silence" and "nothing." Throughout adulthood, he had been the dominant influence in her life, much as Sam had been during her childhood and Ellis during her youth. Unlike Sam and Ellis, however, with Joe there were no regrets. They had created a complete unit filled with love, music, and intellectual pursuits; they had shared everything. Without Joe, she was left with a deep sense of loneliness and vulnerability:

When the evening's over

I go out into the dark alone,

chill by my side

chill before and behind me.

I am a house without walls.

(Kirsch - unpublished)

\section{Bibliography}

Bletchley Park. Home of the Code Breakers. Archive. Milton Keynes, Buckinghamshire, England.

Beneven-Botha, Chaim. 1998."'n Brief." DE KAT. June 1998. 84-86

Celliers, Jan F.E. 1934. Die Vlakte en Ander Gedigte. Cape Town: Nasionale Pers Bpk. 
Death Certificate of Samuel Meyer Kirsch. 1937. In possession of J. Hirschman.

Diaspora Museum. Archive. Tel Aviv, Israel.

Gillis, J. Recorded interview: name of interviewee not recorded. In possession of A. Zohar.

Hirschman, J. Personal interviews. April 2009 - February 2014.

Hugo, Daniel. 2006. “Olga Kirsch (1924-1997)." Perspektief en Profiel: 'n Afrikaanse

Literatuurgeskiedenis III. Ed. H.P. van Coller. Pretoria: J.L. Van Schaik.

Human, Piet. Personal Interview. August 2009

Kirsch, Olga. 1941. Eunice High School Magazine. Bloemfontein. Dec. 1941. n.pag. 1944. Die Soeklig. Pretoria: J.L. van Schaik.

1948. Mure van die Hart. Johannesburg: Afrikaanse Pers Boekhandel.

1971. "Vyf Sonnette vir my Vader." Buurman. Dec. 1971.

1972. Negentien Gedigte. Kaapstad: Human and Rousseau.

1976. Geil Gebied. Kaapstad: Human and Rousseau.

1982. Afskeide. Kaapstad: Human and Rousseau.

1982. Eva's Story. Unpublished. Collection of J. Hirschman.

1994. Nou spreek ek weer bekendes aan: 'n Keur 1944-1983. Ed. Daniel Hugo.

Kaapstad: Human and Rousseau.

Lasker, Carol. 2003. “Olga Kirsch: Ghost, Memories, Emotions.” Metamorphoses: A Journal of Literary Translation 11.2. Fall: 44-45.

Lyons, Michal. Personal interviews. June 2009 - July 2012.

Marriage Certificate of Joseph Gillis and Olga Kirsch. 1949. Haifa. In possession of A. Zohar.

Newman, A.N., ed. 2006. Jewish Migration to South Africa: The Records of the Poor Jews'

Temporary Shelter, 1885-1914. Cape Town: Jewish Publications South Africa.

Marais, Eugène. 1984. Versamelde werke. Ed. Leon Rousseau.Pretoria: J.L. van

Schaik. 14 June 2014. <http:/ / www.dbnl.org/tekst/mara002vers01_01/ mara002vers01_01_0175.php\#173>.

Minnaar, William Frank Thomas. 2012. “A Re-evaluation of Olga Kirsch's Oeuvre: Identity, Maternity and Exile in the Light of the Psychoanalytical Theories of, Among Others,

Sigmund Freud, Jacques Lacan and Julia Kristeva," Diss. University of Cape Town.

Shakespeare, William. 1982. Hamlet: Act 3, scene 1, lines 60-64. The Illustrated Stratford Shakespeare. London: Chancellor Press.

Shapiro, Arnold. Personal interviews. August 2009 -August 2010.

Telfed. South African Zionist Federation. Archive.Ranana, Israel.

University of the Witwatersrand. Archive.August 2011.

Wessels, Andries. 2009. "The outsider as insider: The Jewish Afrikaans poetry of Olga Kirsch." Prooftexts 29.1. Winter: 63-85.

Yoffee, Betty. Personal interviews. November 2012 - June 2013.

Yudeiken, I. Personal interviews. June 2009 - August 2010.

Yudeiken, Sheila. Personal interviews. June 2009 - August 2010.

Zohar, Ada. Personal interviews. April 2009 - February 2014. 